\title{
Model Sistem Dinamik untuk Evaluasi Skenario Pengelolaan Sampah di Kota Depok
}

\author{
Dynamic System Model for Evaluation on Waste Management \\ Scenario in Depok City
}

\author{
Ika Artika1 \\ Direktorat Jenderal Cipta Karya \\ Kementerian Pekerjaan Umum dan Perumahan Rakyat, Jakarta, Indonesia

\section{Mochammad Chaerul} \\ Program Studi Teknik Lingkungan, Fakultas Teknik Sipil dan Lingkungan \\ Institut Teknologi Bandung, Bandung, Indonesia
}

Artikel Masuk : 22 April 2020

Artikel Diterima : 25 November 2020

Tersedia Online : 31 Desember 2020

\begin{abstract}
Abstrak: Salah satu program pemerintah untuk mencapai target Kebijakan dan Strategi Nasional Pengelolaan Sampah adalah dengan membangun tempat pemrosesan akhir sampah (TPA) regional. Untuk mendukung operasional TPA regional, pemerintah daerah yang memanfaatkan TPA regional perlu menyiapkan kebijakan dan strategi untuk mengoptimalkan pelayanan pengelolaan sampah di wilayahnya. Kota Depok merupakan salah satu dari empat kota yang akan dilayani oleh Tempat Pengolahan dan Pemrosesan Akhir Sampah Regional Lulut Nambo (TPPAS Nambo). Tujuan penelitian ini adalah menganalisis berbagai alternatif skenario kebijakan guna mengoptimalkan pelayanan pengelolaan sampah di Kota Depok dan mengetahui pengaruhnya terhadap sampah yang terangkut ke TPPAS Nambo. Metode analisis kebijakan yang digunakan adalah simulasi model dengan pendekatan sistem dinamik. Simulasi dilakukan dari tahun 2020 hingga 2045. Terdapat empat skenario yaitu skenario business as usual, skenario A optimalisasi fasilitas pengolahan sampah eksisting, skenario B sesuai dengan program-program kebijakan dan strategi daerah dalam pengelolaan sampah, dan skenario C untuk mencapai target $30 \%$ pengurangan. Hasil simulasi menunjukkan timbulan sampah Kota Depok pada tahun 2045 diperkirakan sebesar 3.426 ton/hari. Semua skenario yang diuji masih memberikan hasil jumlah sampah terangkut ke TPA yang melebihi kuota sampah ke TPPAS Nambo. Dari skenario C, diperoleh selisih jumlah sampah yang membutuhkan pemrosesan di TPA lokal pada tahun 2045 paling sedikit sebesar 1.180 ton/hari. Timbulan sampah Kota Depok sangat besar dan akan terus meningkat sehingga penambahan fasilitas pengolahan dan lahan urug TPA lokal masih sangat diperlukan hingga 26 tahun ke depan. Kebutuhan lahan urug dapat ditekan dengan meningkatkan pengolahan sampah, namun hal ini membutuhkan biaya pengelolaan sampah yang semakin mahal.
\end{abstract}

Kata Kunci: pengelolaan sampah; sampah perkotaan; simulasi model; sistem dinamik

\footnotetext{
${ }^{1}$ Korespondensi Penulis: Direktorat Jenderal Cipta Karya Kementerian Pekerjaan Umum dan Perumahan Rakyat, Jakarta, Indonesia Email: ikaartika96@gmail.com
} 


\title{
262 Model Sistem Dinamik untuk Evaluasi Skenario Pengelolaan Sampah di Kota Depok
}

\begin{abstract}
One of the government programs to achieve the target of the National Waste Management Policy and Strategy is to build a regional landfill. To support regional landfill operations, the local governments which have utilized regional landfill need to prepare policies and strategies for optimizing waste management services in their area. Depok City is one of four cities that will served by Nambo Regional Landfill. The purpose of this study was to analyze various alternative policy scenarios to optimize waste management services in Depok City and determine their effects on the amount of waste transported to Nambo Regional Landfill. The policy analysis method used simulation model with a dynamic system approach. The simulation was conducted from 2020 to 2045. There were four scenarios, namely business as usual scenario, scenario $A$ for the optimization of existing waste treatment facilities, scenario $B$ which was based on local waste management policies and strategies, and scenario C for achieving 30\% target of waste reduction. The simulation results showed the waste generation in 2045 was estimated to reach 3,426 tons/day. Results from all scenarios showed that the amount of waste disposed to landfill exceeds the maximum waste input to Nambo Regional Landfill. From scenario C, the amount of waste to be processed in the local landfill in 2045 was at least 1,180 tons/day. Depok City has a huge amount of waste and will continue to increase, so it is necessary to add waste treatment facilities and local landfill for the next 26 years. Landfill needs can be reduced by increasing waste treatment, but it requires greater waste management costs.
\end{abstract}

Keywords: model simulation; urban solid waste; system dynamics; waste management

\section{Pendahuluan}

Pemerintah Republik Indonesia (2017) melalui Peraturan Presiden (Perpres) Nomor 97 Tahun 2017 tentang Kebijakan dan Strategi Nasional (Jakstranas) Pengelolaan Sampah Rumah Tangga dan Sampah Sejenis Sampah Rumah Tangga menetapkan target pengurangan sampah sebesar 30\% dan penanganan sampah sebesar $70 \%$ pada akhir tahun 2025. Pemerintah provinsi dan pemerintah kabupaten/kota berkewajiban menyusun Kebijakan dan Strategi Daerah (Jakstrada) bidang persampahan di daerahnya masingmasing dengan berpedoman pada Jakstranas Persampahan. Untuk mencapai target pengurangan dan penanganan sampah tersebut, pemerintah melakukan berbagai upaya salah satunya dengan membangun tempat pemrosesan akhir (TPA) sampah regional.

TPA sampah regional adalah TPA sampah yang dikelola secara bersama-sama oleh dua atau lebih kabupaten/kota dalam satu provinsi. TPA sampah regional merupakan alternatif solusi untuk kabupaten/kota yang kesulitan memperoleh lahan atau lokasi untuk TPA. Namun, tantangan yang umumnya dihadapi pemerintah daerah (Pemda) dalam memanfaatkan TPA regional seperti biaya tipping fee yang lebih mahal, jarak tempuh ke TPA regional yang lebih jauh, dan biaya operasional pengangkutan yang menjadi lebih tinggi, membuat Pemda perlu menyiapkan kebijakan dan strategi untuk meningkatkan pelayanan pengelolaan sampah di wilayahnya untuk mereduksi sampah yang diangkut ke TPA.

Pengelolaan sampah merupakan kegiatan yang kompleks dan dinamis. Kompleks karena dipengaruhi berbagai aspek seperti peraturan, kelembagaan, keuangan, teknis, dan partisipasi masyarakat (Damanhuri \& Padmi, 2019). Dinamis karena dengan meningkatnya jumlah penduduk maka jumlah timbulan sampah akan terus meningkat dan sarana prasarana pengelolaan sampah juga perlu ditingkatkan. Dalam meningkatkan pelayanan pengelolaan sampah, tidak bisa hanya pada salah satu aspek saja, tetapi harus secara holistik. Untuk menganalisis dan memilih skenario kebijakan mana yang terbaik dalam meningkatkan pelayanan pengelolaan sampah dapat digunakan simulasi pemodelan.

Salah satu pemodelan yang umum digunakan dalam analisis kebijakan pengelolaan sampah adalah pemodelan dengan pendekatan sistem dinamik (Popli et al., 2017). 
Pemodelan sistem dinamik dapat membantu untuk mempelajari struktur dan dinamika dari sistem yang kompleks sehingga dapat mudah dipahami bagaimana suatu sistem bekerja. Kegunaan lainnya yaitu untuk memprediksi kinerja masa depan dari sistem yang telah ada, mengevaluasi skenario kebijakan sehingga diperoleh kebijakan dengan dampak yang tinggi, serta membantu merancang intervensi dalam sistem yang dapat mempercepat keberhasilan sesuai kondisi sistem yang diharapkan (Deaton \& Winebrake, 2000; Sterman, 2002). Sistem dinamik juga dapat membantu untuk mengetahui bagaimana interaksi antarvariabel pengelolaan sampah dan mengetahui variabel yang berperan penting (Chaerul et al., 2008; Kollikkathara et al., 2010; Manasakunkit \& Chinda, 2017). Pemodelan sistem dinamik sudah banyak digunakan untuk mencari alternatif skenario yang efektif dalam mengurangi sampah (Fauzan, 2017; Rahayu et al., 2013; Zulfinar \& Sembiring, 2015), menurunkan biaya pengelolaan sampah (Kholil, 2005; Yudiyanto, 2007), meningkatkan kualitas lingkungan (Bala et al., 2017), memperpanjang usia pakai lahan urug (Giannis et al., 2017; Handono, 2010; Yudiyanto, 2007), dan meningkatkan cakupan pelayanan (Abraham et al., 2017; Febriyanto, 2016; Wildanurrizal et al., 2014), serta memperoleh operasional pengelolaan yang stabil dan berkelanjutan secara ekonomi dan lingkungan (Cai \& Liu, 2013).

Tujuan penelitian ini adalah menganalisis berbagai alternatif skenario kebijakan guna mengoptimalkan pelayanan pengelolaan sampah di Kota Depok dan mengetahui pengaruhnya terhadap sampah yang terangkut ke TPPAS Nambo. Alternatif skenario kebijakan dilakukan dengan mengembangkan model sistem dinamik pengelolaan sampah yang melibatkan timbulan sampah, kapasitas fasilitas pengolahan sampah, kapasitas pengangkutan, biaya pengelolaan sampah, dan emisi lingkungan. Melalui pemodelan sistem dinamik ini, diharapkan dapat membantu memberikan rekomendasi kebijakan bagi Pemerintah Daerah (Pemda) untuk meningkatkan pelayanan pengelolaan sampah di Kota Depok sehingga dapat mereduksi sampah yang terangkut ke TPA.

Model yang dikembangkan ini melibatkan banyak aspek pengelolaan sampah mulai dari hulu sampai hilir. Kelebihan model ini adalah variabel yang digunakan untuk menggambarkan aspek teknis operasional dan aspek pembiayaan lebih rinci dibandingkan model pada studi terdahulu. Struktur model yang disusun berdasarkan kondisi pengelolaan sampah pada umumnya di Indonesia sehingga juga dapat diaplikasikan untuk kota-kota lainnya. Variabel data input lebih rinci serta berdasarkan data yang pada umumnya tersedia dan data output yang dihasilkan juga lebih banyak. Dengan demikian penelitian ini diharapkan dapat melengkapi studi-studi terdahulu yang berkaitan dengan pemodelan pengelolaan sampah dan memberikan hasil yang lebih akurat.

\section{Metode Penelitian}

Data yang diperlukan untuk menyusun model diperoleh dari wawancara dan data sekunder dari instansi pemerintahan terkait serta hasil penelitian terdahulu. Data yang dikumpulkan adalah data kependudukan dan kondisi ekonomi yang diperoleh dari Badan Pusat Statistik (BPS). Kemudian data kondisi pengelolaan sampah seperti timbulan sampah, sumber sampah, komposisi sampah, data historis sampah yang dikelola pada fasilitas pengolahan sampah dan TPA, diperoleh dari Dinas Lingkungan Hidup (DLH) dan Kementerian Pekerjaan Umum dan Perumahan Rakyat (PUPR).

Metode analisis kebijakan yang digunakan adalah simulasi model dengan menggunakan perangkat lunak STELLA 9.1.3. Pengembangan model dimulai dengan konseptualisasi terhadap sistem pengelolaan sampah yang dituangkan dalam bentuk causal loop diagram. Lalu struktur model disusun dalam bentuk stock flow diagram. Kemudian model dievaluasi dan diuji validitasnya dengan membandingkan hasil simulasi sistem dinamik dengan data historis. Validasi model menggunakan dua cara pengujian yaitu mean 


\section{Model Sistem Dinamik untuk Evaluasi Skenario Pengelolaan Sampah di Kota Depok}

comparison (E1) dan error variance (E2) yang persamaannya dapat dilihat pada Tabel 1. Setelah model dianggap valid, disusun skenario-skenario alternatif untuk meningkatkan pelayanan pengelolaan sampah. Skenario-skenario tersebut disimulasikan dalam model sistem dinamik dan hasilnya dianalisis untuk memilih skenario terbaik sebagai usulan kebijakan.

Tabel 1. Rumus Validasi Hasil Simulasi

\begin{tabular}{ll}
\hline \multicolumn{1}{c}{ Mean Comparison } & \multicolumn{1}{c}{ Error variance } \\
\cline { 1 - 2 }$=\frac{|\bar{S}-\bar{A}|}{\bar{A}}$ & $E 2=\frac{|S s-S a|}{S a}$ \\
Keterangan: & Keterangan: \\
$\bar{S}=$ Nilai rata-rata hasil simulasi & $\mathrm{Ss}=$ Standar deviasi hasil simulasi \\
$\bar{A}=$ Nilai rata-rata data & $\mathrm{Sa}=$ Standar deviasi data \\
Model dianggap valid apabila E1 $\leq 5 \%$. & Model dianggap valid apabila E2 $\leq 30 \%$. \\
\hline Sumber: Barlas 1989 &
\end{tabular}

Sumber: Barlas, 1989

\section{Kondisi Eksisting Sistem Pengelolaan Sampah Kota Depok}

Pertumbuhan penduduk dan ekonomi adalah dua faktor utama yang memengaruhi jumlah timbulan sampah kota (Al-Khatib et al., 2015; Giannis et al., 2017). Berdasarkan data BPS, jumlah penduduk di Kota Depok terus mengalami kenaikan dengan laju pertumbuhan penduduk selama lima tahun terakhir dari 2014 hingga 2018 yang terus mengalami penurunan rata-rata 0,07\%/tahun (Gambar 1a). Pada tahun 2018, jumlah penduduk sebanyak 2.330.333 jiwa dengan laju pertumbuhan penduduk tahun 2017-2018 sebesar $3,36 \%$. Variabel-variabel ekonomi yang ditinjau adalah peningkatan pendapatan per kapita, pertumbuhan sektor industri, dan pertumbuhan sektor pertanian (Damanhuri \& Padmi, 2019). Variabel ekonomi ini diukur dari nilai produk domestik regional bruto (PDRB). Gambar 1b menunjukkan bahwa pada periode 2014-2018, PDRB atas dasar harga konstan (ADHK) mengalami kenaikan dengan laju rata-rata pertumbuhan sebesar 6,85\%/tahun. Sementara laju rata-rata pertumbuhan PDRB sektor industri nonmigas sebesar $3,72 \% /$ tahun dan sektor pertanian sebesar $2,2 \% /$ tahun.

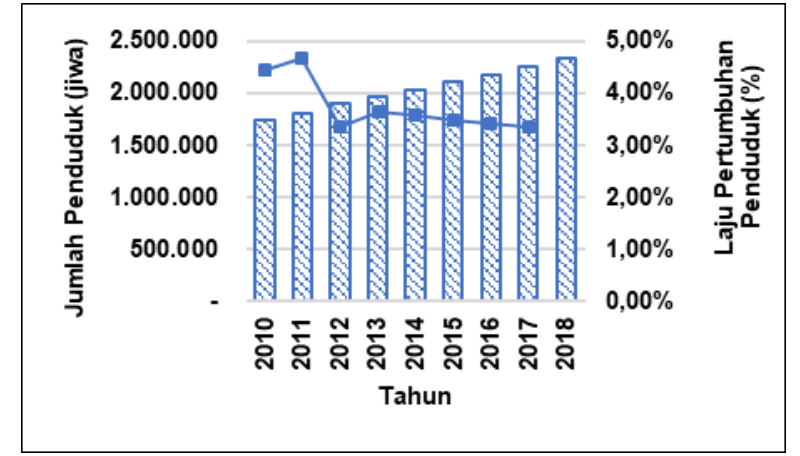

(a)

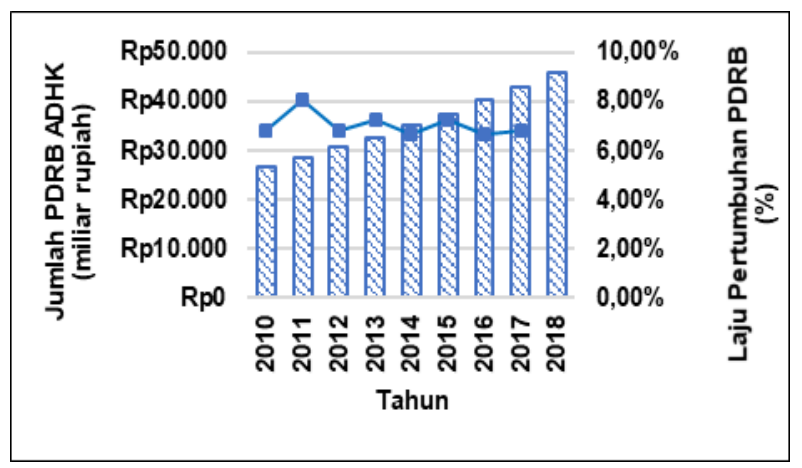

(b)

Sumber: BPS Kota Depok, 2019

\section{Gambar 1. Kondisi Sosioekonomi Kota Depok Tahun 2010-2018 (a) Berdasarkan Jumlah Penduduk dan (b) Berdasarkan Jumlah PDRB ADHK}

Komposisi sampah merupakan hal penting yang harus diperhatikan dalam merencanakan pengelolaan sampah. Berdasarkan Rencana Induk Sistem Pengelolaan Sampah Kota Depok Tahun 2017-2036 (Masterplan Persampahan), timbulan sampah ekivalensi sebesar 0,588 kg/orang/hari (Bappeda Kota Depok, 2017). Nilai ini sudah 
memperhitungkan sampah permukiman dan nonpermukiman. Komposisi sampah didominasi oleh sampah mudah terurai sebesar 67,27\%, sampah tidak mudah terurai atau yang dapat didaur ulang seperti plastik, kertas, logam, kain, karet, dan kaca sebesar $21,70 \%$, serta sampah residu sebesar $11,03 \%$. Sampah paling banyak berasal dari rumah tangga 62,67\%, pasar tradisional 9,33\%, dan kawasan 9,33\% (Kementerian Lingkungan Hidup dan Kehutanan, 2018).

Pada tahun 2019, timbulan sampah kota diperkirakan sebesar 1.444,2 ton/hari dengan tingkat pelayanan sampah tertangani mencapai 65,5\%. Sampah tertangani yaitu sampah yang dikelola melalui Bank Sampah Unit (BSU), Unit Pengolahan Sampah (UPS), dan sampah yang langsung diangkut ke TPA. Tabel 2 menunjukkan data fasilitas pengolahan sampah di Kota Depok. Bank sampah di Kota Depok masih belum maksimal dengan tiap unitnya diperkirakan rata-rata hanya melayani 89 kepala keluarga (KK). Jumlah yang terlayani UPS sudah cukup banyak namun ternyata UPS hanya berkontribusi sebesar $5,98 \%$ terhadap total timbulan sampah. Porsi sampah terangkut langsung ke TPA masih lebih besar. Pada periode Januari-September 2019, sampah terangkut ke TPA Cipayung sebanyak 858,44 ton/hari. Neraca massa pengelolaan sampah Kota Depok tahun 2019 dapat dilihat pada Gambar 2. Nilai pada neraca massa diolah berdasarkan data timbulan sampah kota, sampah terolah di fasilitas pengolahan sampah, dan sampah terangkut ke TPA Cipayung yang diperoleh dari DLH Kota Depok.

Tabel 2. Data Fasilitas Pengolahan Sampah Kota Depok

\begin{tabular}{lcrrl}
\hline Komponen & Satuan & $\begin{array}{c}\text { Bank } \\
\text { Sampah Unit } \\
\text { (BSU) }\end{array}$ & $\begin{array}{c}\text { Unit } \\
\text { Pengolahan } \\
\text { Sampah (UPS) }\end{array}$ & \multicolumn{1}{c}{ Keterangan } \\
\hline Jumlah & Unit & 426 & 32 & Sumber: DLH Kota Depok, \\
Sampah yang & Ton/hari & 9,1 & 86,4 & 2019 (data diolah) \\
dikelola & Ton/hari/unit & 0,021 & 2,7 & \\
Rata-rata & KK/unit & 89 & 1.607 & Data diolah dengan asumsi yang \\
jumlah & & & & masuk ke BSU 10\% dan UPS \\
terlayani & & & & $70 \%$ dari timbulan sampah \\
Total terlayani & KK & 37.914 & 51.424 & ekivalensi \\
\hline
\end{tabular}

Sumber: Data diolah, 2019

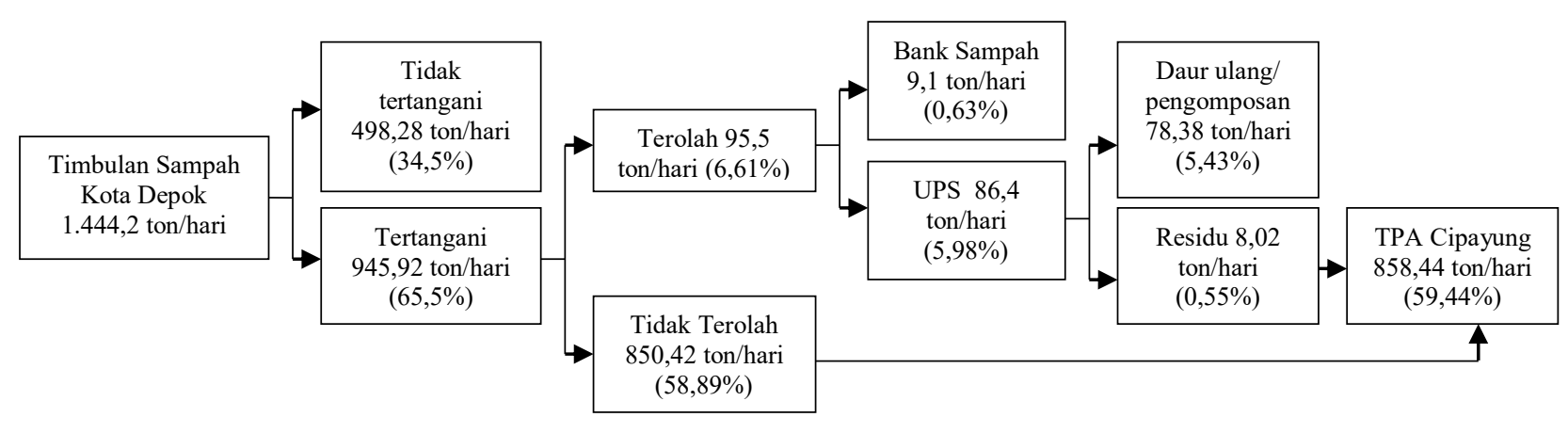

Sumber: Data diolah, 2019

\section{Gambar 2. Neraca Massa Pengelolaan Sampah Kota Depok Tahun 2019}

Tingkat pelayanan persampahan di Kota Depok belum mencapai 100\%. Data tingkat pelayanan pada tahun 2017 berdasarkan Dokumen Masterplan Persampahan baru mencapai $59,6 \%$. Berdasarkan hasil pengolahan data yang dilakukan penulis, tingkat pelayanan pada tahun 2019 diperkirakan naik menjadi 65,5\% (Gambar 2). Kenaikan ini 


\section{Model Sistem Dinamik untuk Evaluasi Skenario Pengelolaan Sampah di Kota Depok}

karena dominan dipengaruhi oleh penambahan armada pengangkutan sampah oleh DLH Kota Depok sehingga semakin banyak sampah yang diangkut langsung ke TPA.

Tiap-tiap kota yang dilayani Tempat Pengolahan dan Pemrosesan Akhir Sampah Regional (TPPAS) Nambo memiliki jatah kuota sampah. Jumlah sampah Kota Depok yang dapat diterima TPPAS Nambo minimal 600 ton/hari dan maksimal 700 ton/hari (Tabel 3). Namun diketahui jumlah sampah terangkut pada tahun 2019 sudah melebihi kuota tersebut. Oleh karena itu, terdapat selisih sampah yang masih harus ditangani di TPA lokal yaitu TPA Cipayung. Di sisi lain, kondisi TPA Cipayung juga sudah melebihi kapasitas sehingga diperlukan penambahan lahan urug baru.

\section{Gambaran Umum TPPAS Regional Lulut Nambo}

TPPAS Regional Lulut Nambo yang berlokasi di Kecamatan Klapanunggal, Kabupaten Bogor, berjarak sekitar $30 \mathrm{~km}$ dari pusat kota Depok. Pembangunan dan pengelolaan TPPAS Nambo berada dalam kewenangan UPTD Pengelolaan Sampah TPA/TPST Regional (PSTR) DLH Jawa Barat. TPPAS ini direncanakan untuk melayani sampah rumah tangga dari Kota Depok, Kota Bogor, Kabupaten Bogor, dan Kota Tangerang Selatan. Kuantitas sampah yang dapat diterima TPPAS Nambo dari masingmasing wilayah ditunjukkan pada Tabel 3 . Kegiatan yang direncanakan di TPPAS yaitu pemilahan sampah, pengomposan, pengolahan sampah menjadi refuse derived fuel (RDF) dan pemrosesan residu sampah secara saniter (sanitary landfill). RDF diperoleh dari kombinasi proses pengolahan mekanis dan biologis, dengan hasil akhir berbentuk pelet. RDF biasanya dimanfaatkan sebagai bahan bakar alternatif untuk pembangkit listrik dan industri semen (Archer et al., 2005; Ochiai et al., 2015).

Tabel 3. Kuantitas Sampah yang Diterima di TPPAS Nambo

\begin{tabular}{|c|c|c|c|}
\hline \multirow{2}{*}{ No } & \multirow{2}{*}{ Penerima Layanan TPPAS Nambo } & \multicolumn{2}{|c|}{ Kuota Kuantitas (ton/hari) } \\
\hline & & Minimal & Maksimal \\
\hline 1 & Kabupaten Bogor & 500 & 600 \\
\hline 2 & Kota Bogor & 400 & 500 \\
\hline 3 & Kota Depok & 600 & 700 \\
\hline 4 & Kota Tangerang Selatan & 300 & 500 \\
\hline & Jumlah & 1.800 & 2.300 \\
\hline
\end{tabular}

Sumber: UPTD PSTR Jawa Barat, 2018

\section{Kebijakan Pengelolaan Sampah Kota Depok}

Kebijakan dan Strategi Pengelolaan Sampah (Jakstrada) Kota Depok diatur dalam Peraturan Walikota Depok No. 65 Tahun 2018 (Pemerintah Kota Depok, 2018). Dalam Jasktrada tersebut, ditargetkan pada tahun 2025 seluruh sampah terkelola dengan kegiatan pengurangan sampah mencapai $30 \%$ dan penanganan sampah mencapai $70 \%$. Program fisik untuk meningkatkan pengolahan sampah berupa target penambahan bank sampah sebanyak 1 unit/tahun. Selain itu, terdapat juga program penguatan komitmen dunia usaha melalui penerapan kewajiban produsen dalam pengurangan sampah (extended producer responsility/EPR).

\section{Pengembangan Model}

Model sistem dinamik pengelolaan sampah tersusun dari empat submodel yaitu submodel timbulan sampah di sumber, submodel teknis operasional, submodel pembiayaan, dan submodel beban emisi. Hubungan antarvariabel penyusun model digambarkan melalui causal loop diagram (CLD) yang terdapat pada Gambar 3. Kemudian tahap selanjutnya dibuat stock flow diagram (SFD) dari masing-masing submodel (Gambar 
4, Gambar 5, Gambar 6, dan Gambar 7). Interaksi antarvariabel ditandai dengan simbol anak panah. Tanda positif pada garis panah artinya perubahan nilai di satu variabel mengakibatkan perubahan nilai di variabel yang lain dalam arah yang berbanding lurus. Sementara tanda negatif artinya perubahan nilai di satu variabel mengakibatkan perubahan nilai di variabel yang lain dalam arah yang berbanding terbalik. Apabila diagram terbentuk loop, maka diberi tanda feedback loop. Terdapat dua jenis feedback loop yaitu simbol positif/reinfocing loop (R) yang menunjukkan pertumbuhan yang terus-menerus di sistem dan negatif/balancing loop yang menunjukkan bahwa terdapat hubungan yang saling bertolak belakang di sistem (Campuzano \& Mula Bru, 2011).

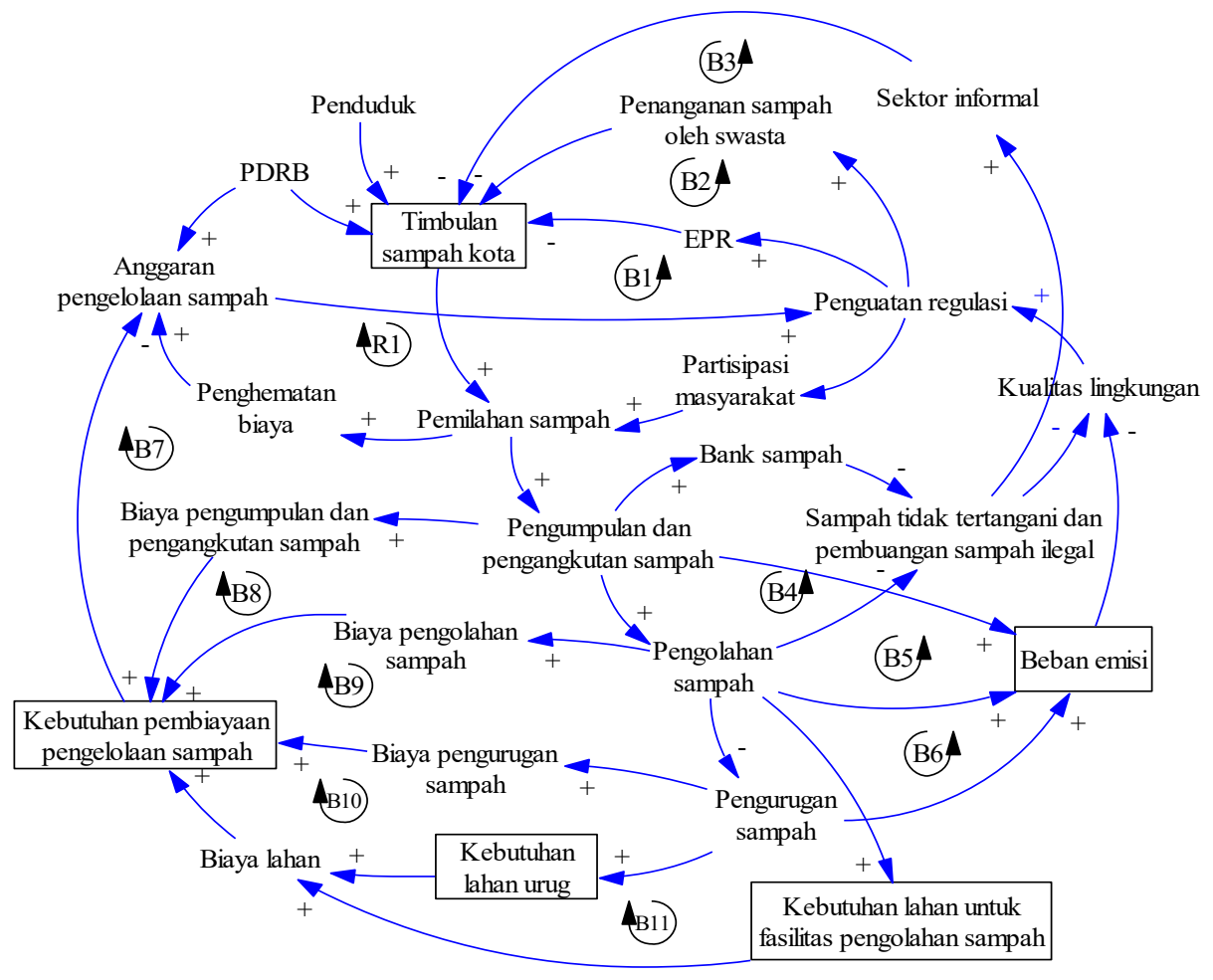

Gambar 3. Causal Loop Diagram Pengelolaan Sampah

CLD yang disusun pada penelitian ini menggambarkan model konseptual yang ditargetkan untuk mengakomodasi banyak variabel pengelolaan sampah yang terdapat dalam Jakstrada Persampahan (Gambar 3). Timbulan sampah dipengaruhi oleh dua faktor utama yaitu pertumbuhan penduduk dan PDRB. Masyarakat diharapkan memilah sampah di sumber sebelum dikumpulkan dan diangkut ke fasilitas pengolahan sampah. Sampah anorganik yang bernilai ekonomis dapat dikumpulkan ke bank sampah. Dengan semakin banyaknya sampah yang diolah, diharapkan sampah tidak tertangani dan pembuangan sampah ilegal yang dapat mencemari lingkungan menurun. Untuk mencegah pencemaran lingkungan, pemerintah mengeluarkan beberapa regulasi di antaranya mendorong masyarakat untuk memilah sampah di sumber, menerapkan skema EPR dan mewajibkan pengelola kawasan (swasta) untuk mengelola sampahnya sendiri. Selain itu, terdapat sektor informal yang juga berperan untuk mengurangi timbulan sampah. Adanya pemilahan sampah dapat menghemat biaya karena teknologi pengolahan sampah yang digunakan lebih sederhana dan kebutuhan lahan untuk fasilitas pengolahan sampah dan pengurugan sampah lebih sedikit. Biaya pengelolaan sampah adalah total biaya dari tahap pengumpulan dan pengangkutan, pengolahan, pengurugan sampah. Dalam model ini 


\section{Model Sistem Dinamik untuk Evaluasi Skenario Pengelolaan Sampah di Kota Depok}

terlihat bahwa penguatan regulasi berperan penting dalam sistem pengelolaan sampah, yang ditandai dengan banyaknya anak panah keluar dari variabel ini, dan penguatan regulasi ini sangat dipengaruhi oleh anggaran pengelolaan sampah.

\section{Submodel Timbulan Sampah di Sumber}

Gambar 4 menunjukkan SFD submodel timbulan sampah di sumber. Submodel ini menggambarkan prediksi total timbulan sampah setiap tahun simulasi seiring dengan peningkatan populasi penduduk dan perubahan ekonomi yang memengaruhi timbulan sampah per kapita. Selain itu, hasil simulasi lain yang juga diperoleh adalah dinamika sampah terpilah dan tidak terpilah.

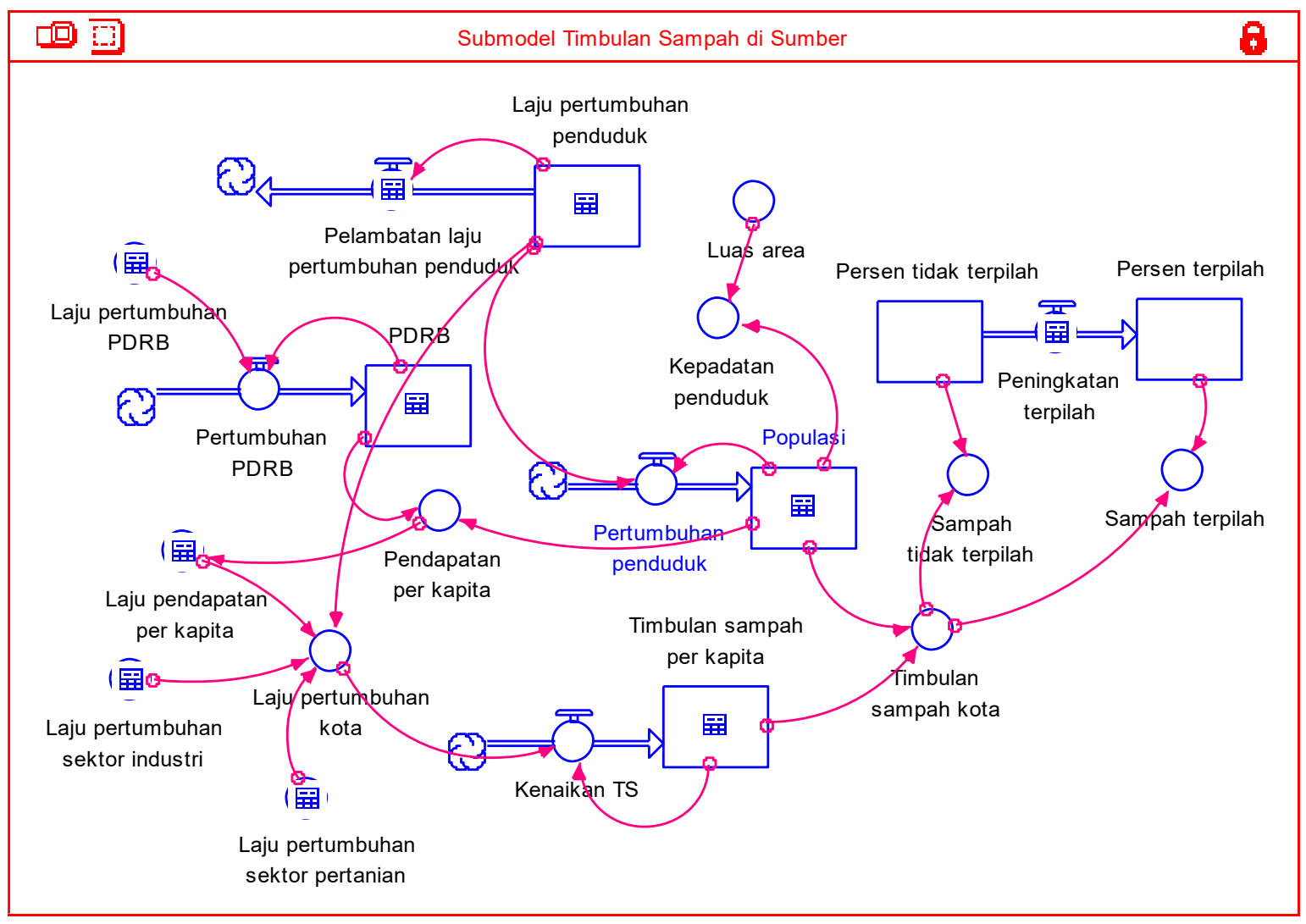

Gambar 4. SFD Submodel Timbulan Sampah di Sumber

\section{Submodel Teknis Operasional}

Gambar 5 menunjukkan SFD submodel teknis operasional dalam pengelolaan sampah. Variabel yang bergaris putus-putus menandakan adanya interkoneksi dengan submodel lainnya. Submodel ini bertujuan menggambarkan pengaruh peningkatan pelayanan pengelolaan sampah terhadap kegiatan pengumpulan, pengolahan, pengangkutan, dan kebutuhan lahan. Hasil yang diperoleh dari submodel ini adalah jumlah sampah tertangani oleh DLH, produsen, dan swasta, jumlah sampah diurug, kebutuhan armada pengumpulan dan pengangkutan, kapasitas bank sampah, kapasitas tempat pengolahan sampah berbasis 3R (TPS 3R) atau UPS, kapasitas tempat pengolahan sampah terpadu (TPST), kebutuhan lahan untuk fasilitas pengolahan sampah dan lahan urug. Selain itu, juga akan diselidiki berapa jumlah sektor informal (dalam hal ini pemulung) yang 
dibutuhkan untuk mengelola sampah tidak tertangani. Asumsi pada perhitungan jumlah pemulung mengacu kepada penelitian Manasakunkit \& Chinda (2017).

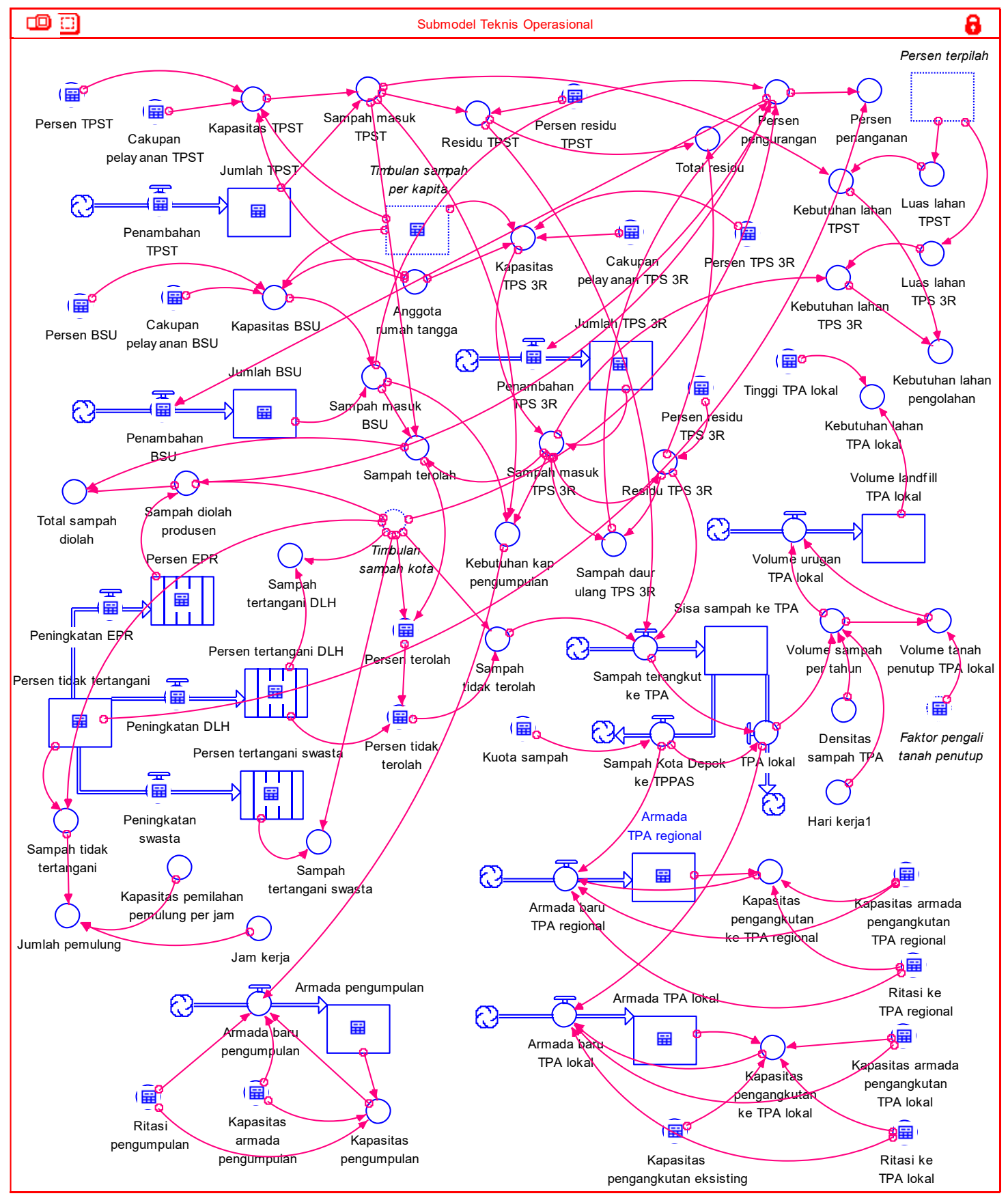

Gambar 5. SFD Submodel Teknis Operasional

\section{Submodel Pembiayaan Pengelolaan Sampah}

SFD pada Gambar 6 bertujuan untuk mengetahui dinamika kebutuhan pembiayaan pengelolaan sampah. Hasil yang diperoleh dari submodel ini adalah kebutuhan biaya investasi dan biaya operasional dan pemeliharaan (OP). Biaya investasi terdiri dari pembangunan fasilitas pengolahan sampah, lahan urug, dan pengadaan truk sampah. 
Sementara perhitungan biaya OP meliputi OP layanan TPS 3R/UPS dan TPST, OP pengangkutan, OP TPA lokal, tipping fee, dan biaya tol ke TPPAS Nambo.

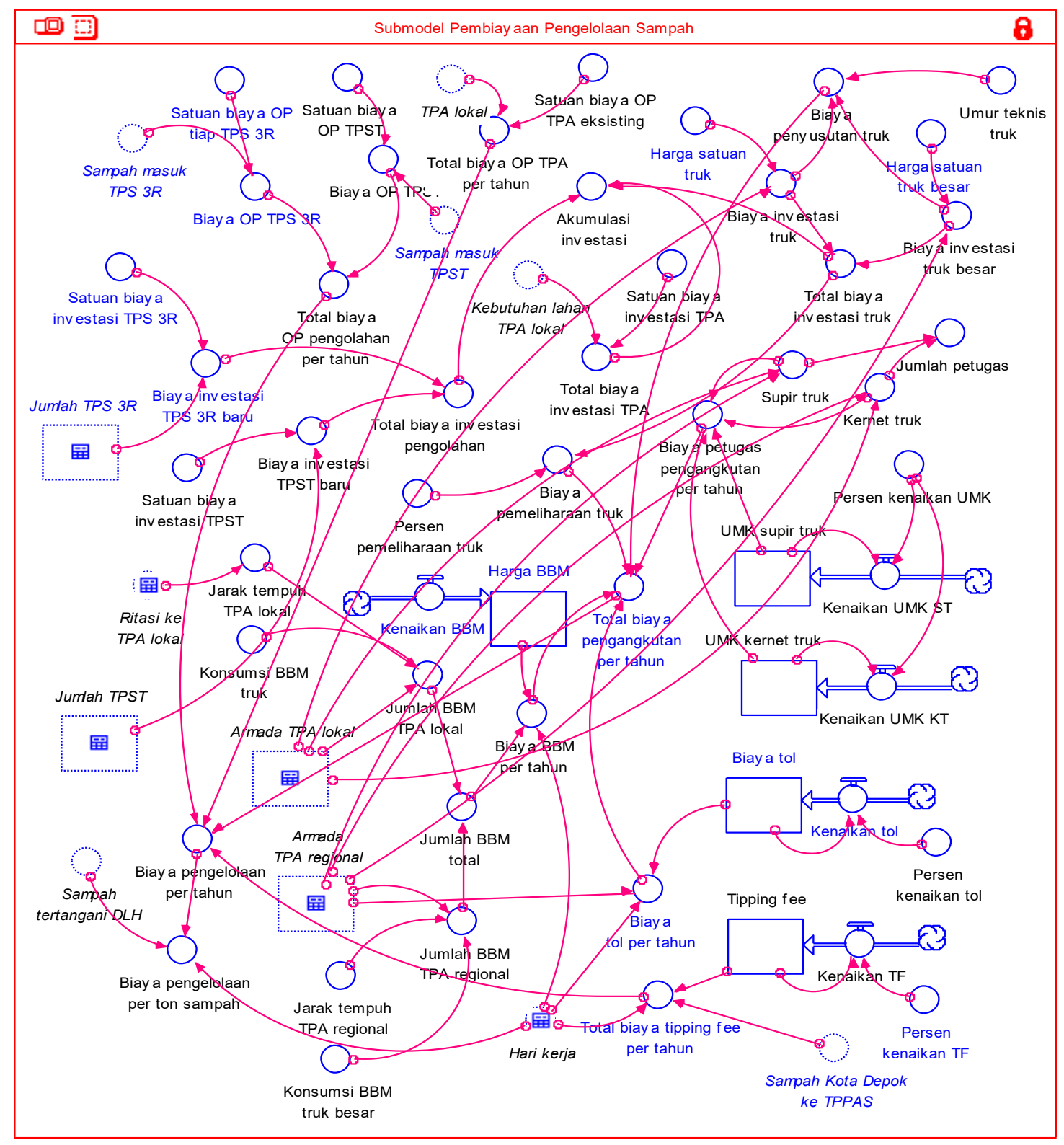

\section{Gambar 6. SFD Submodel Pembiayaan Pengelolaan Sampah}

\section{Submodel Beban Emisi}

SFD pada Gambar 7 bertujuan untuk menggambarkan emisi dari kegiatan pengelolaan sampah. Hasil yang diperoleh dari submodel ini adalah dinamika emisi $\mathrm{CO}_{2} \mathrm{eq}$ dari kegiatan pengolahan sampah, pengangkutan sampah, dan dekomposisi lahan urug. Emisi pengolahan sampah ditinjau dari pengolahan sampah secara biologis dan pengolahan sampah secara termal. Emisi pengolahan biologis bersumber dari pengomposan sampah makanan dan sampah mudah terurai lainnya yang masuk ke TPS 3R/UPS. Sementara emisi pengolahan termal bersumber dari pengolahan di TPST yang diasumsikan menggunakan insinerator. 


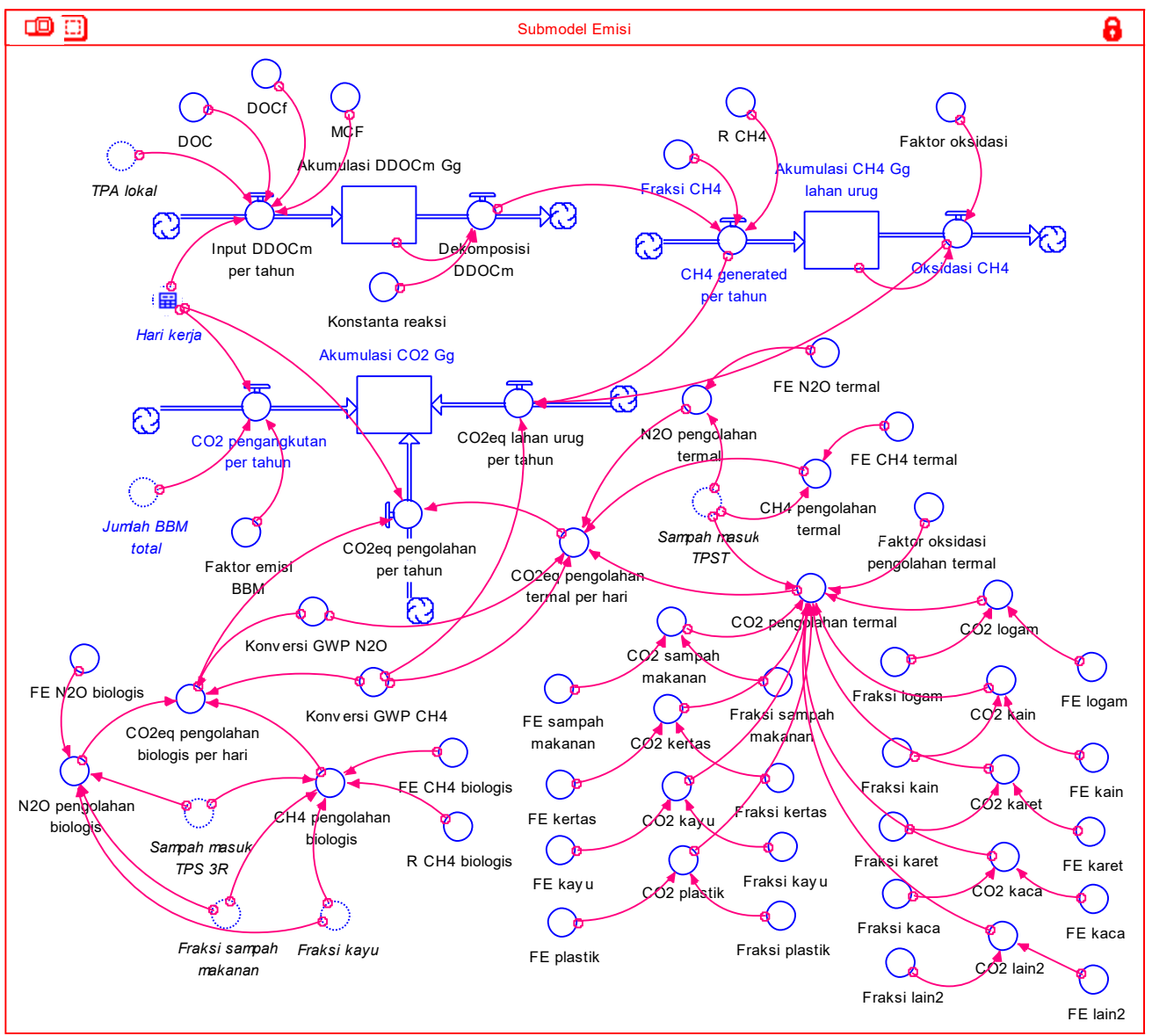

Gambar 7. SFD Submodel Beban Emisi

\section{Validasi Model}

Validasi model dilakukan untuk memastikan hasil simulasi sudah sesuai dengan kondisi nyata dan dapat diterima. Validasi dilakukan terhadap data historis persampahan Kota Depok dari tahun 2014 hingga 2018. Data angka dan asumsi yang dimasukkan pada saat validasi model adalah data saat kondisi business as usual. Tidak semua data hasil simulasi dapat divalidasi karena adanya keterbatasan data historis. Tabel 4 menunjukkan hasil dari beberapa variabel yang divalidasi dan diperoleh nilai mean comparison (E1) $<5 \%$ dan error variance (E2) < 30\%. Dengan demikian hasil simulasi dari model ini dapat dikatakan valid.

Tabel 4. Hasil Uji Validasi Model

\begin{tabular}{lccc}
\hline \multicolumn{1}{c}{ Variabel } & Mean Comparison (\%) & Error Variance (\%) & Keterangan \\
\hline Populasi penduduk & $0,000816 \%$ & $0,011115 \%$ & Valid \\
PDRB & $0,007850 \%$ & $0,285636 \%$ & Valid \\
Pendapatan per kapita & $0,006925 \%$ & $0,636451 \%$ & Valid \\
Jumlah sampah terangkut & $4,497615 \%$ & $6,510310 \%$ & Valid \\
\hline
\end{tabular}

\section{Penyusunan Skenario Kebijakan}

Simulasi model dilakukan dari tahun 2020 hingga 2045. Pada penyusunan skenario alternatif diasumsikan bahwa pada 2025 cakupan pelayanan telah mencapai $100 \%$. TPA 


\section{Model Sistem Dinamik untuk Evaluasi Skenario Pengelolaan Sampah di Kota Depok}

yang digunakan adalah TPPAS Nambo dan apabila sampah melebihi kuota sampah masuk ke TPPAS maka akan digunakan TPA lokal. Skenario-skenario yang disimulasikan yaitu, pertama Skenario Business as Usual (BAU), yang bertujuan untuk melihat perubahan kondisi di masa depan apabila dibiarkan mengikuti kecenderungan pada kondisi di masa sekarang. Kedua, Skenario A yang disusun dengan fokus untuk melihat pengaruh dari optimalisasi fasilitas pengolahan sampah eksisting ketika tingkat pelayanan persampahan mencapai $100 \%$. Pada skenario A ini tidak ada penambahan fasilitas pengolahan sampah. Ketiga, Skenario B, yang disusun dengan fokus untuk melihat seberapa signifikan pengurangan sampah ke TPA apabila mengacu kepada program-program Jakstrada. Pada skenario B ini diasumsikan terdapat pengurangan sampah melalui EPR dan penambahan BSU. Keempat, Skenario C yang bertujuan untuk melihat seberapa signifikan pengurangan sampah ke TPA apabila target Jakstrada yaitu 30\% pengurangan dan $70 \%$ penanganan tercapai serta terus dijaga nilainya hingga tahun-tahun berikutnya. Pada skenario $\mathrm{C}$ ini diasumsikan terdapat pengurangan sampah melalui EPR, keterlibatan swasta untuk menangani sampahnya sendiri, serta penambahan BSU, UPS, dan TPST. Berdasarkan skenario-skenario yang telah disusun, ditentukan parameter-parameter dan nilai pada setiap skenario seperti yang dapat dilihat pada Tabel 5.

Tabel 5. Parameter dan Asumsi dalam Skenario

\begin{tabular}{|c|c|c|c|c|c|}
\hline \multirow[b]{2}{*}{ Parameter } & \multirow[b]{2}{*}{ Satuan } & \multirow[b]{2}{*}{$\begin{array}{l}\text { Dasar } \\
(2019)\end{array}$} & \multicolumn{3}{|c|}{ Target 2045} \\
\hline & & & $\begin{array}{c}\text { Skenario } \\
\text { A }\end{array}$ & $\begin{array}{c}\text { Skenario } \\
\text { B }\end{array}$ & $\begin{array}{c}\text { Skenario } \\
\text { C }\end{array}$ \\
\hline Persentase EPR & $\%$ & - & - & $10 \%{ }^{a}$ & $10 \%^{\mathrm{a}}$ \\
\hline Persentase tertangani DLH & $\%$ & $65,5 \%$ & $100 \%{ }^{\mathrm{a}}$ & $90 \%{ }^{a}$ & $80 \%{ }^{a}$ \\
\hline Persentase tertangani swasta & $\%$ & - & - & - & $10 \%{ }^{\mathrm{a}}$ \\
\hline Persentase tidak tertangani & $\%$ & $34,5 \%$ & - & - & - \\
\hline Peningkatan persentase EPR & $\% /$ tahun & - & - & $2 \%$ & $2 \%$ \\
\hline Peningkatan persentase tertangani DLH & $\% /$ tahun & $1,00 \%$ & $5,75 \%$ & $4,08 \%$ & $2,42 \%$ \\
\hline Peningkatan persentase swasta & $\% /$ tahun & - & - & - & $2 \%$ \\
\hline Penambahan BSU & Unit/tahun & - & - & 1 & 20 \\
\hline Penambahan UPS & Unit/tahun & - & - & - & 5 \\
\hline Penambahan TPST & Unit/tahun & - & - & - & 1 \\
\hline Cakupan pelayanan BSU & KK & 89 & 350 & 350 & 350 \\
\hline Cakupan pelayanan UPS & KK & 1.607 & 2000 & 2000 & 2000 \\
\hline Cakupan pelayanan TPST & KK & - & - & - & 5000 \\
\hline Persentase residu UPS & $\%$ & $9,28 \%$ & $30 \%{ }^{\mathbf{b}}$ & $30 \% \mathbf{0}^{\mathbf{b}}$ & $30 \% \mathbf{b}$ \\
\hline 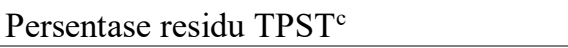 & $\%$ & - & $10 \%$ & $10 \%$ & $10 \%$ \\
\hline
\end{tabular}

Keterangan: (a) target tercapai tahun 2025; (b) presentase residu menjadi naik karena diasumsikan seluruh jenis sampah masuk ke UPS dari yang sebelumnya hanya mengolah sampah mudah terurai; dan (c) asumsi jenis pengolahan sampah adalah insinerator.

\section{Hasil dan Pembahasan}

\section{Timbulan Sampah Kota}

Dalam prediksi dinamika timbulan sampah kota, pendekatan sistem dinamik mampu mengakomodasi berbagai faktor yang memengaruhi perhitungan serta melacak ketidakpastian yang apabila menggunakan model statistik tidak mampu mengakomodasi hal tersebut (Dyson \& Chang, 2005). Timbulan sampah kota umumnya dihitung berdasarkan jumlah penduduk dan timbulan sampah per kapita. Perubahan timbulan sampah per kapita dipengaruhi oleh peningkatan pendapatan per kapita, pertumbuhan sektor industri, dan pertumbuhan sektor pertanian (Damanhuri \& Padmi, 2019). 


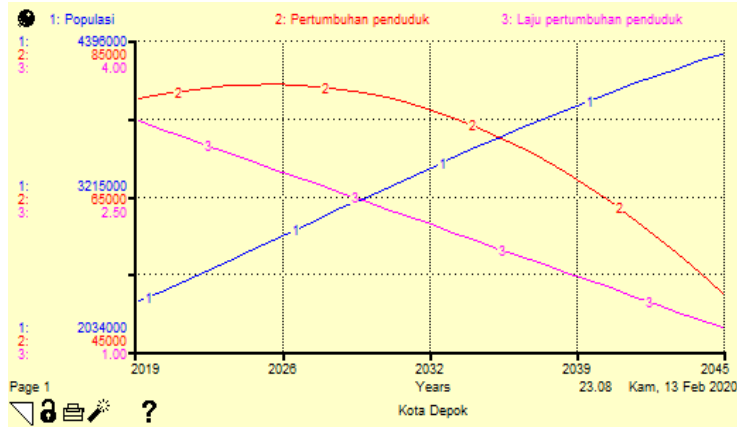

(a)

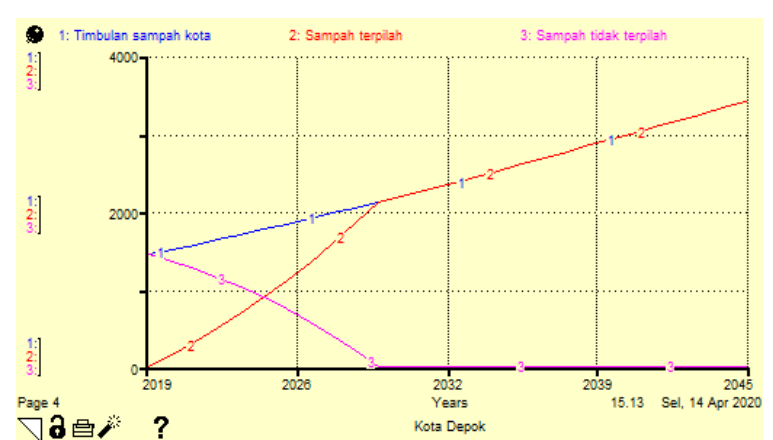

(b)

Gambar 8. Hasil Simulasi Submodel Timbulan Sampah di Sumber Tahun 2020-2045

(a) Berdasarkan Hasil Simulasi Jumlah Penduduk dan Pertumbuhan Penduduk dan (b) Berdasarkan Hasil Simulasi Timbulan Sampah dan Pemilahan Sampah

Hasil simulasi yang terdapat pada Gambar 8a memperlihatkan jumlah penduduk akan terus meningkat dengan kondisi laju pertumbuhan penduduk yang terus mengalami penurunan sebesar 0,07\%/tahun. Pada tahun 2045, diperkirakan jumlah penduduk Kota Depok yang semula 2.407.008 jiwa pada tahun 2019 naik mencapai 4.396 .037 jiwa dan timbulan sampah per kapita yang semula $0,6 \mathrm{~kg} / \mathrm{orang} / \mathrm{hari}$ naik menjadi 0,78 $\mathrm{kg} /$ orang/hari. Kenaikan ini menunjukkan pola konsumsi penduduk yang semakin konsumtif.

Gambar 8b memperlihatkan hasil simulasi timbulan sampah kota yang terus mengalami kenaikan serta kondisi pemilahan sampah. Dengan asumsi kenaikan tingkat pemilahan sampah oleh masyarakat sebesar 10\%/tahun, maka tingkat pemilahan sampah $100 \%$ akan tercapai pada tahun 2029. Hasil simulasi menunjukkan timbulan sampah Kota Depok yang semula pada tahun 2019 sebanyak 1.444 ton/hari meningkat pada tahun 2045 menjadi 3.426 ton/hari. Nilai ini jauh melebihi dari kuota sampah TPPAS Nambo yang hanya menerima 700 ton/hari, sehingga masih ada selisih 2.726 ton/hari yang harus ditangani pemerintah daerah.

\section{Sampah Terangkut ke TPA}

Hasil simulasi dari skenario A, B, dan C adalah berdasarkan kondisi apabila tingkat pelayanan mencapai $100 \%$ pada tahun 2025 sesuai target Jakstrada. Sementara bila mengikuti skenario BAU yang diperkirakan kenaikan tingkat pelayanan hanya sebesar 1\%/tahun, maka pada akhir tahun 2045 tingkat pelayanan 100\% tidak akan tercapai dan hanya mencapai $88 \%$. Hasil simulasi dari semua skenario yang ditunjukkan Gambar 9a memperlihatkan bahwa skenario $C$ yaitu pengurangan sampah $30 \%$ memberikan hasil jumlah sampah yang terangkut paling sedikit, namun jumlah tersebut masih melebihi kuota sampah masuk ke TPPAS Nambo yaitu maksimal 700 ton/hari. Kelebihan kuota sampah ini karena penambahan kapasitas pengolahan sampah pada semua skenario masih terlalu kecil bila dibandingkan dengan pertumbuhan timbulan sampah yang lebih besar. Pada tahun 2045, sampah terangkut pada skenario BAU diperkirakan 3.021 ton/hari, skenario A sebesar 3.193 ton/hari, skenario B sebesar 2.845 ton/hari, dan skenario C sebesar 1.880 ton/hari. Selisih jumlah sampah yang membutuhkan pemrosesan di TPA lokal dari masingmasing skenario secara berurutan adalah 2.321 ton/hari, 2.493 ton/hari, 2.145 ton/hari, dan 1.180 ton/hari. Sejalan dengan studi-studi terdahulu yang dilakukan Fauzan (2017), Rahayu et al. (2013), Zulfinar \& Sembiring (2015), hasil simulasi ini juga memperlihatkan bahwa semakin optimis upaya pengurangan sampah yang direncanakan, maka semakin sedikit jumlah sampah di pengolahan akhir. Dengan adanya kombinasi pengurangan 


\section{Model Sistem Dinamik untuk Evaluasi Skenario Pengelolaan Sampah di Kota Depok}

sampah melalui EPR, keterlibatan swasta, dan pengolahan sampah secara termal dalam skenario $\mathrm{C}$, dapat mengurangi sampah secara signifikan.

\section{Kebutuhan Lahan}

Jumlah timbulan sampah dan sampah terangkut ke TPA menunjukkan jumlah yang sangat besar bila dibandingkan dengan jatah kuota sampah ke TPPAS Nambo sehingga pemerintah daerah tetap perlu menggunakan TPA lokal untuk mengatasi selisih sampah tersebut. Namun, kondisi TPA Cipayung saat ini sudah melebihi kapasitas dan diperlukan penambahan lahan urug baru sehingga dalam penelitian ini juga akan dihitung berapa kebutuhan lahan urug tersebut. Gambar 9b menunjukkan hasil simulasi penambahan lahan untuk UPS, TPST, dan lahan urug pada tahun 2045. Pada skenario BAU diasumsikan tingkat pelayanan belum mencapai $100 \%$ di tahun 2025 dan penambahannya mengikuti kecenderungan yang ada. Sementara tingkat pelayanan pada skenario A, B, dan C pada tahun 2025 diasumsikan telah tercapai $100 \%$ sesuai target Jakstrada, sehingga hasil pada skenario A dan B menunjukkan kebutuhan lahan yang lebih luas dibanding skenario BAU. Hasil simulasi memperlihatkan porsi kebutuhan lahan paling besar dari semua skenario adalah lahan urug. Adanya usaha pengurangan sampah akan memperpanjang usia lahan urug (Intani, 2017; Kollikkathara et al., 2010; Yudiyanto, 2007). Sejalan dengan hal tersebut, hasil simulasi skenario B dan C menunjukkan peningkatan jumlah bank sampah dan pengolahan sampah di UPS dan TPST membuat kebutuhan lahan urug berkurang signifikan. Dengan demikian dapat disimpulkan total lahan yang dibutuhkan menunjukkan pengurangan seiring dengan peningkatan pengolahan sampah.

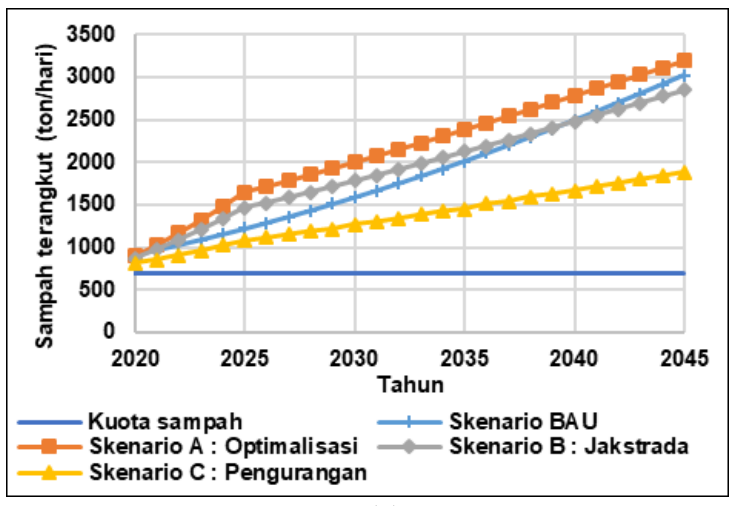

(a)

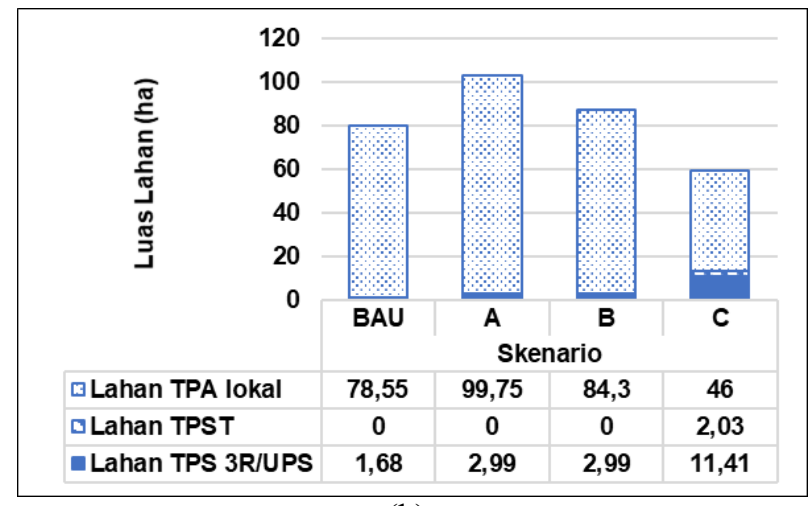

(b)

Gambar 9. Hasil Simulasi Submodel Teknis Operasional Tahun 2045 (a) Berdasarkan Hasil Simulasi Sampah Terangkut ke TPA dan (b) Berdasarkan Kebutuhan Lahan untuk Fasilitas Pengolahan Sampah dan Lahan Urug TPA Lokal

\section{Biaya Pengelolaan Sampah}

Dari hasil simulasi semua skenario pada tahun 2045 yang ditunjukkan pada Gambar 10a, diketahui bahwa skenario C membutuhkan biaya investasi paling tinggi. Sementara biaya OP dari setiap skenario menunjukkan perbedaan yang tidak signifikan. Gambar 10b memperlihatkan besarnya kontribusi dari tiap-tiap komponen perhitungan biaya investasi. Pada skenario A dan B, komponen biaya investasi yang paling mahal adalah lahan urug. Sementara itu pada skenario C, komponen biaya pengolahan lebih mahal karena terdapat penambahan TPST secara berkala. Hasil simulasi menunjukkan seiring dengan meningkatnya biaya pengolahan, maka biaya pengangkutan dan biaya TPA lokal juga akan menurun. 


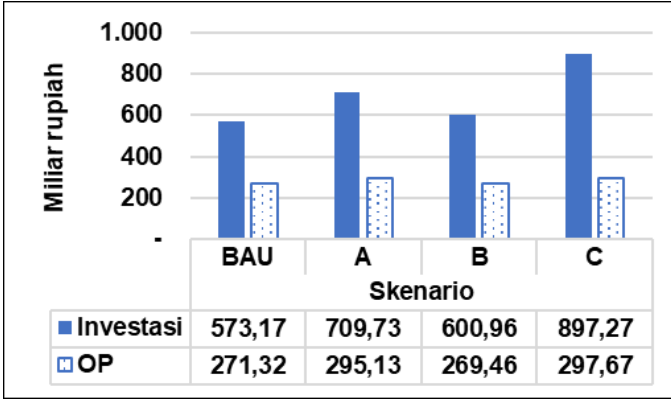

(a)

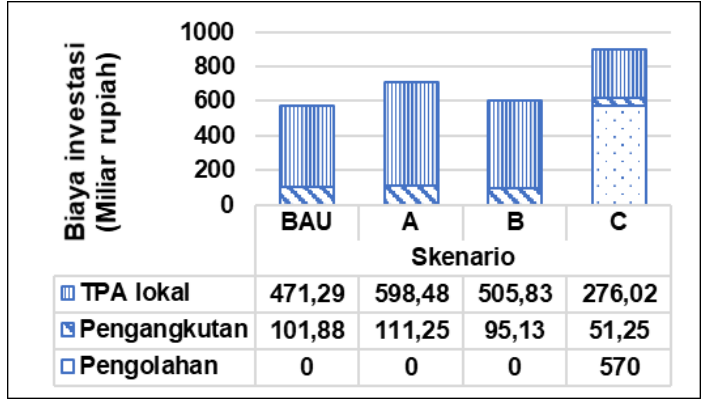

(b)

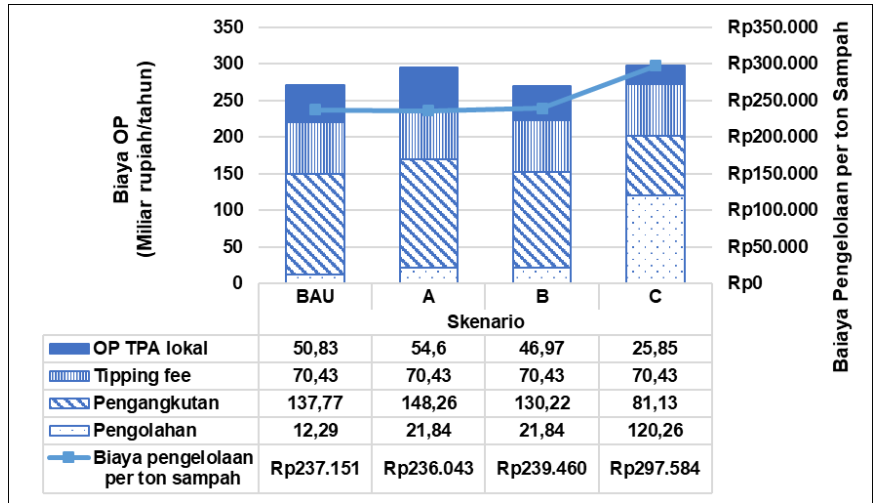

(c)

Gambar 10. Hasil Simulasi Submodel Pembiayaan Pengelolaan Sampah Tahun 2045 (a) Berdasarkan Kebutuhan Biaya Investasi, Biaya Operasional dan Pemeliharaan, (b) Berdasarkan Rincian Biaya Investasi yang Dibutuhkan, dan (c) Berdasarkan Rincian Biaya OP yang Dibutuhkan dan Biaya Pengelolaan per ton Sampah

Gambar 10c memperlihatkan rincian biaya OP dan biaya pengelolaan per ton sampah. Pada skenario A dan B, komponen biaya OP terbesar adalah biaya pengangkutan, sedangkan pada skenario $C$ adalah biaya pengolahan. Pada skenario $B$ juga terlihat bahwa dengan kombinasi antara pengurangan melalui EPR dan penambahan 1 unit bank sampah per tahun mampu menurunkan biaya pengangkutan dan biaya OP TPA lokal. Namun hal ini tidak menaikkan biaya pengolahan sampah yang ditanggung pemerintah daerah karena pembiayaan bank sampah seluruhnya dikelola masyarakat. Sementara itu, dari skenario C kombinasi antara EPR, keterlibatan swasta dan penambahan fasilitas pengolahan sampah baik secara biologis maupun termal, terlihat bahwa secara keseluruhan kenaikan biaya OP ternyata tidak signifikan. Perbedaan yang tidak signifikan ini karena sebenarnya terjadi peralihan biaya yang semula dialokasikan untuk pengangkutan dan TPA menjadi untuk pengolahan sampah.

Hasil pada skenario B yang menunjukkan adanya penurunan biaya dibandingkan skenario A, sejalan dengan penelitian Al-Khatib et al. (2015) dan Intani (2017) yang menyatakan adanya upaya pengurangan sampah dapat mengurangi biaya pengelolaan sampah. Namun, pada skenario $C$ yang memberikan hasil pengurangan sampah paling rendah, ternyata membutuhkan biaya yang lebih tinggi. Perbedaan ini terjadi karena pada skenario C digunakan pengolahan sampah secara termal. Sementara umumnya pada penelitian terdahulu, upaya pengurangan sampah dilakukan melalui peningkatan pengolahan secara biologis yang biaya investasi dan OP jauh lebih rendah dibandingkan pengolahan termal.

Biaya pengelolaan per ton sampah diperoleh dari total biaya OP dibagi sampah yang tertangani DLH. Hasil perhitungan biaya per ton sampah yang tidak linier dengan total 


\section{Model Sistem Dinamik untuk Evaluasi Skenario Pengelolaan Sampah di Kota Depok}

biaya OP karena jumlah sampah yang tertangani DLH dari setiap skenario tidak sama. Sampah yang tertangani DLH pada skenario B dan C lebih sedikit karena diasumsikan ada upaya pengurangan melalui EPR dan keterlibatan swasta. Secara keseluruhan terlihat dari semua skenario tidak menunjukkan perbedaan biaya OP yang signifikan. Namun bila ditinjau dari biaya pengelolaan per ton sampah, akan terlihat bahwa biaya pengelolaan semakin mahal. Semakin mahalnya biaya pengelolaan per ton sampah, meskipun sampah yang tertangani semakin sedikit, menunjukkan bahwa skenario B dan C yang disusun belum terlalu efisien.

\section{Beban Emisi}

Gambar 11 memperlihatkan dinamika beban emisi yang dihasilkan dari kegiatan pengolahan sampah, pengangkutan sampah, dan pemrosesan di TPA lokal. Dari rekapitulasi hasil emisi $\mathrm{CO}_{2}$ eq/tahun pada tahun 2045 yang terdapat pada Gambar 12, dapat dilihat bahwa emisi paling besar dihasilkan dari dekomposisi lahan urug TPA. Meskipun tingkat pelayanan $100 \%$ pada skenario A, ternyata emisi yang dihasilkan tidak jauh berbeda dari skenario BAU. Adanya peningkatan pengolahan sampah seperti yang terdapat pada skenario B dan C, menunjukkan penurunan total emisi/tahun karena emisi yang dihasilkan dari proses pengolahan sampah lebih kecil bila dibandingkan dengan emisi lahan urug. Hal ini juga sejalan dengan penelitian Bala et al. (2017) yang menyatakan bahwa peningkatan kapasitas pengolahan sampah merupakan aspek penting untuk meningkatkan kualitas lingkungan.

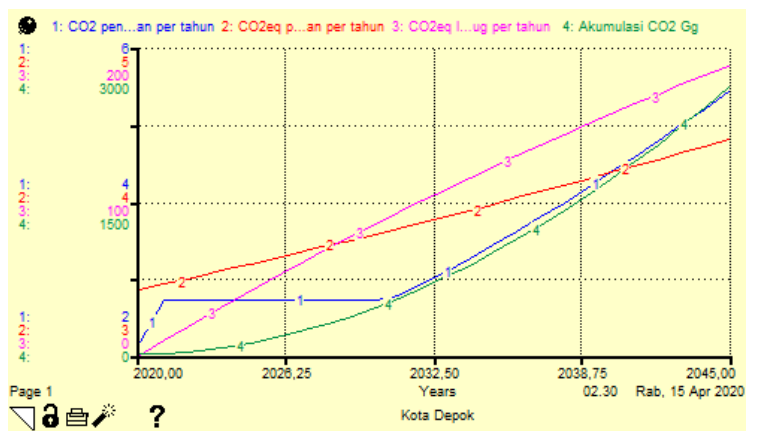

(a)

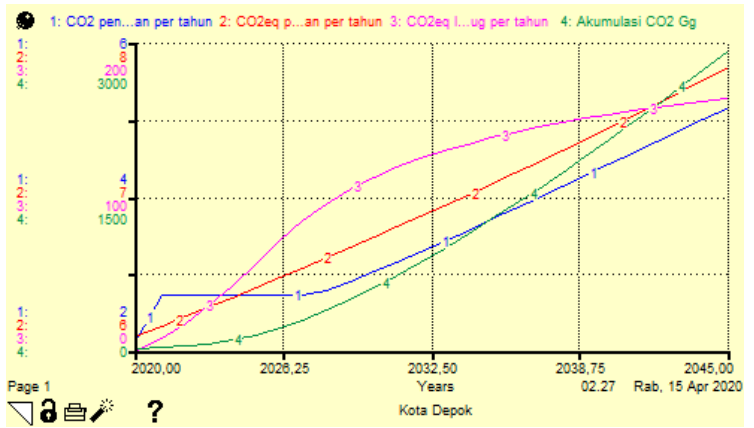

(c)

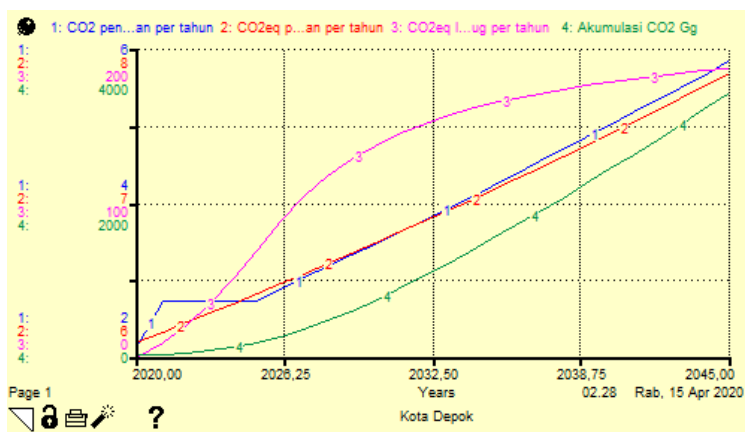

(b)

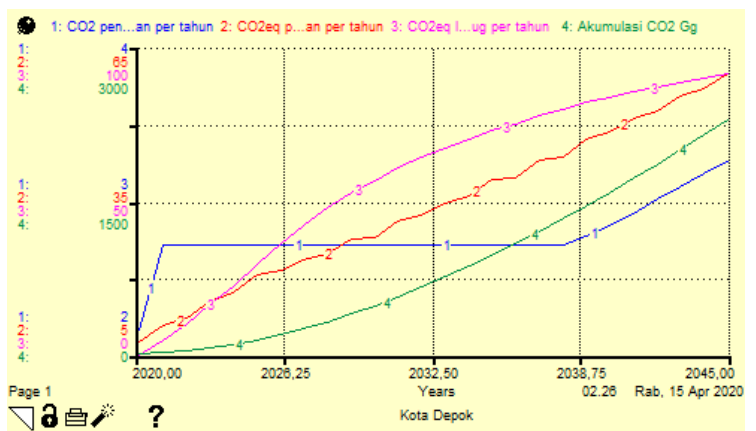

(d)

Keterangan: garis biru: emisi dari pengolahan sampah, garis merah: emisi dari pengangkutan sampah, garis merah muda: emisi dari lahan urug, dan garis hijau: emisi dari seluruh kegiatan pengelolaan sampah.

Gambar 11. Hasil Simulasi Beban Emisi Kegiatan Pengelolaan Sampah Tahun 2020-2045 (a) Berdasarkan Hasil Simulasi Beban Emisi Skenario BAU, (b) Hasil Simulasi Beban Emisi Skenario A, (c) Hasil Simulasi Beban Emisi Skenario B, dan (d) Hasil Simulasi Beban Emisi Skenario C 


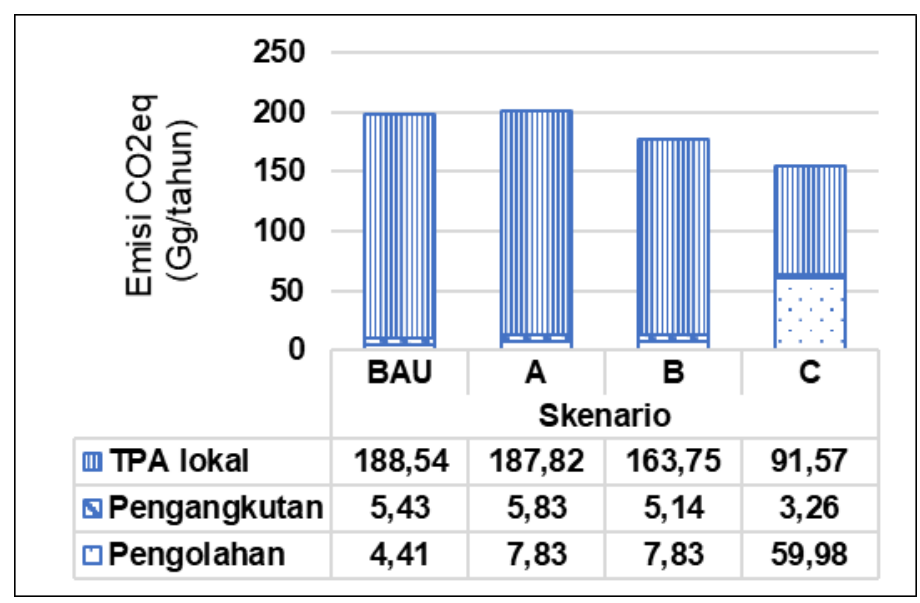

Gambar 12. Hasil Simulasi Beban Emisi $\mathrm{CO}_{2}$ eq Tahun 2045

\section{Kesimpulan}

Kriteria-kriteria yang digunakan dalam memilih skenario terbaik adalah skenario yang menghasilkan nilai terendah pada sampah terangkut ke TPA, kebutuhan lahan, biaya pengelolaan sampah, dan beban emisi. Dari hasil simulasi, terlihat bahwa timbulan sampah Kota Depok akan terus meningkat setiap tahunnya, dan pada tahun 2045 diperkirakan sebesar 3.426 ton/hari. Hasil simulasi skenario BAU menunjukkan sampah terangkut ke TPA yang selalu melebihi kuota sampah ke TPPAS Nambo yang menerima maksimal hanya 700 ton/hari. Di tahun 2045, sampah terangkut pada skenario BAU diperkirakan mencapai 3.021 ton/hari. Dengan disimulasikannya beberapa skenario kebijakan pengurangan sampah, didapat hasil jumlah sampah terangkut ke TPA dari skenario A sebesar 3.193 ton/hari, skenario B sebesar 2.845 ton/hari, dan skenario C sebesar 1.880 ton/hari. Semua skenario yang disimulasikan menunjukkan meskipun sudah terdapat berbagai upaya pengurangan sampah seperti penambahan fasilitas pengolahan sampah yang signifikan, keterlibatan swasta untuk menangani sampah sendiri, dan peningkatan EPR, namun masih belum mampu mengurangi sampah hingga batas kuota sampah ke TPPAS Nambo.

Kelebihan jumlah sampah tersebut masih perlu ditangani pemerintah daerah dengan menambah area TPA lokal. Selisih jumlah sampah yang membutuhkan pemrosesan di TPA lokal paling rendah ditunjukkan pada skenario C sebesar 1.180 ton/hari. Dalam hal kebutuhan lahan dan beban emisi, skenario $C$ juga menunjukkan nilai yang lebih rendah dibanding skenario lainnya. Kebutuhan lahan untuk pengolahan sampah dan lahan urug pada skenario $C$ sebesar 59,44 ha dan menghasilkan beban emisi $\mathrm{CO}_{2}$ eq sebanyak 154,81 $\mathrm{Gg}$ /tahun pada tahun 2045. Namun terkait pembiayaan, skenario C membutuhkan biaya investasi dan biaya OP yang lebih mahal. Biaya pengelolaan sampah yang diperlukan sebesar Rp297.584/ton sampah. Dari kriteria-kriteria pemilihan skenario terbaik yang telah disebutkan di awal, skenario yang hampir memenuhi semua kriteria tersebut adalah skenario C. Ke depannya diperlukan lebih banyak pengujian skenario agar memperoleh skenario yang lebih efektif dan efisien.

Hasil penelitian ini akan berguna bagi Pemerintah Kota Depok untuk evaluasi Jakstrada Persampahan. Skenario Jakstrada Persampahan saat ini yang direpresentasikan dalam skenario B belum signifikan mengurangi sampah sehingga pemerintah daerah perlu meninjau kembali Jakstrada tersebut. Apabila tingkat pelayanan mencapai $100 \%$ sesuai target Jakstrada, kuota sampah ke TPPAS sebesar 700 ton/hari tidak akan cukup hingga 26 


\section{Model Sistem Dinamik untuk Evaluasi Skenario Pengelolaan Sampah di Kota Depok}

tahun ke depan. Penambahan fasilitas pengolahan sampah membutuhkan biaya investasi dan biaya OP yang sangat mahal, namun lahan yang dibutuhkan akan jauh lebih kecil, terutama bila menggunakan pengolahan termal dibandingkan dengan menyediakan lahan urug baru. Upaya lain yang juga dapat signifikan mengurangi sampah namun tidak menambah beban biaya pengelolaan sampah bagi pemerintah daerah adalah dengan pengurangan sampah melalui EPR dan keterlibatan swasta. Namun, kesuksesan hal ini sangat tergantung pada partisipasi masyarakat sehingga perlu ada ketegasan dan pengawasan dari pemerintah daerah kepada masyarakat dan produsen agar hal tersebut dapat berjalan optimal.

\section{Daftar Pustaka}

Abraham, R., Fauzi, A., \& Nuva, N. (2017). Model simulasi dinamik pengelolaan sampah padat permukiman berbasis program $3 R$ di Kota Bogor. Institut Pertanian Bogor.

Al-Khatib, I., Eleyan, D., \& Garfield, J. (2015). A system dynamics model to predict municipal waste generation and management costs in developing areas. Journal of Solid Waste Technology and Management, 41(2), 109-120. doi:10.5276/JSWTM.2015.109.

Archer, E., Baddeley, A., Klein, A., Schwager, J., \& Whiting, K. (2005). Mechanical-biological-treatment: A guide for decision makers processes, policies, and markets. Retrieved from https://www.cti2000.it/Bionett/BioG-2005-003\%20MBT_Summary_Report_Final.pdf.

Bala, B. K., Arshad, F. M., \& Noh, K. M. (2017). Modelling of solid waste management systems of Dhaka City in Bangladesh. In B. K. Bala, F. M. Arshad, \& K. M. Noh (Eds.), System dynamics (pp. 249-274). Singapore: Springer. doi:10.1007/978-981-10-2045-2_12.

Bappeda Kota Depok. (2017). Rencana induk sistem pengelolaan sampah Kota Depok tahun 2017-2036. Depok: Bappeda Kota Depok.

Barlas, Y. (1989). Multiple tests for validation of system dynamics type of simulation models. European Journal of Operational Research, 42(1), 59-87. doi:10.1016/0377-2217(89)90059-3.

BPS Kota Depok. (2019). Kota Depok dalam angka tahun 2019. Depok: Badan Pusat Statistik Kota Depok.

Cai, L., \& Liu, Y. (2013). Application of system dynamics for municipal waste management in China: A case study of Beijing. In Proceedings of the 31st International Conference of the System Dynamics Society, (pp. 513-543). Cambridge, Massachusetts, USA: System Dynamics Society. Retrieved from https://proceedings.systemdynamics.org/2013/proceed/papers/P1106.pdf.

Campuzano, F., \& Mula Bru, J. (2011). Supply chain simulation. London: Springer-Verlag. doi:10.1007/978-085729-719-8.

Chaerul, M., Tanaka, M., \& Shekdar, A. V. (2008). A system dynamics approach for hospital waste management. Waste Management, 28(2), 442-449. doi:10.1016/j.wasman.2007.01.007.

Damanhuri, E., \& Padmi, T. (2019). Pengelolaan sampah terpadu. Bandung: ITB Press.

Deaton, M., \& Winebrake, J. J. (2000). Dynamic modeling of environmental systems. New York: SpringerVerlag. doi:10.1007/978-1-4612-1300-0.

DLH Kota Depok. (2019). Data pengelolaan sampah Kota Depok. Depok: DLH Kota Depok.

Dyson, B., \& Chang, N.-B. (2005). Forecasting municipal solid waste generation in a fast-growing urban region with system dynamics modeling. Waste Management, 25(7), 669-679. doi:10.1016/j.wasman.2004.10.005.

Fauzan, A. Y. (2017). Strategi pengelolaan sampah untuk mengurangi timbulan sampah plastik (sistem pengelolaan sampah dengan simulasi model sistem dinamik di Pulau Pramuka Kabupaten Adminisrasi Kepulauan Seribu). Universitas Indonesia.

Febriyanto, R. (2016). Strategi pengelolaan sampah kota melalui penerapan alternatif kebijakan lingkungan (Suatu kajian sistem pengelolaan sampah di kota Serang melalui simulasi model System Dynamics). Universitas Indonesia.

Giannis, A., Chen, M., Yin, K., Tong, H., \& Veksha, A. (2017). Application of system dynamics modeling for 
evaluation of different recycling scenarios in Singapore. Journal of Material Cycles and Waste Management, 19, 1177-1185. doi:10.1007/s10163-016-0503-2.

Handono, M. (2010). Model pengelolaan tempat pemrosesan akhir (TPA) sampah secara berkelanjutan di TPA Cipayung Kota Depok-Jawa Barat. Institut Pertanian Bogor.

Intani, E. (2017). Pengaruh reduksi sampah rumah tangga di Kota Bandung terkait konsep regional menggunakan pemodelan sistem dinamik. Institut Teknologi Bandung.

Kementerian Lingkungan Hidup dan Kehutanan. (2018). Data pengelolaan sampah. Retrieved from http://sipsn.menlhk.go.id/.

Kholil, K. (2005). Rekayasa model sistem dinamik pengelolaan sampah terpadu berbasis nirlimbah (zero waste) studi kasus di Jakarta Selatan. Institut Pertanian Bogor.

Kollikkathara, N., Feng, H., \& Yu, D. (2010). A system dynamic modeling approach for evaluating municipal solid waste generation, landfill capacity and related cost management issues. Waste Management, 3a(11), 2194-2203. doi:10.1016/j.wasman.2010.05.012.

Manasakunkit, C., \& Chinda, T. (2017). Development of a municipal solid waste dynamic model in Bangkok, Thailand. Journal of Science Technology, 39(5), 685-695. doi:10.14456/sjst-psu.2017.84.

Ochiai, S., Ishigaki, T., Wangyao, K., \& Yamada, M. (2015). Measurement of the potential heat and ash content of the residue from mechanical biological treatment in Thailand. In The 26th Annual Conference of Japan Society of Material Cycles and Waste Management. doi:10.14912/jsmcwm.26.0_555.

Pemerintah Kota Depok. (2018). Peraturan Wali Kota Depok No. 65 tahun 2018 tentang kebijakan dan strategi Kota Depok dalam pengelolaan sampah rumah tangga dan sampah sejenis sampah rumah tangga.

Pemerintah Republik Indonesia. (2017). Peraturan Presiden No. 97 Tahun 2017 tentang kebijakan dan strategi nasional pengelolaan sampah rumah tangga dan sampah sejenis sampah rumah tangga.

Popli, K., Sudibya, G. L., \& Kim, S. (2017). A review of solid waste management using system dynamics modeling. Journal of Environmental Science International, 26(10), 1185-1200. doi:10.5322/JESI.2017.26.10.1185.

Rahayu, N., Arai, T., Yudoko, G., \& Morimoto, H. (2013). System dynamics models for planning long-term integrated municipal solid waste management in Bandung city. In The Sustainable City VIII (pp. 11531168). WIT Transactions on Ecology and the Environment. doi:10.2495/SC130982.

Sterman, J. (2002). System dynamics: Systems thinking and modeling for a complex world (ESD-WP-200301.13-ESD Internal Symposium). Cambridge, MA: MIT. Retrieved from https://dspace.mit.edu/handle/1721.1/102741.

UPTD PSTR Jawa Barat. (2018). Rencana pembangunan dan pengelolaan TPPAS regional Nambo. UPTD Pengelola Sampah TPA/TPST Regional Provinsi Jawa Barat.

Wildanurrizal, W., Bahauddin, A., \& Ferdinant, P. F. (2014). Perancangan model simulasi pengelolaan sampah dengan pendekatan sistem dinamis di Kota Cilegon. Jurnal Teknik Industri, 2(3). Retrieved from https://jurnal.untirta.ac.id/index.php/jti/article/view/2313.

Yudiyanto, Y. (2007). Analisis sistem pengelolaan sampah permukiman di Kota Bogor. Institut Pertanian Bogor.

Zulfinar, Z., \& Sembiring, E. (2015). Dinamika jumlah sampah yang dihasilkan di Kota Bandung. Jurnal Teknik Lingkungan, 21(1), 18-28. doi:10.5614\%2Fjtl.2015.21.1.3. 